Session 2356

\title{
AN UPPER DIVISION GENERAL EDUCATION COURSE ON MATERIALS FOR NON-ENGINEERING STUDENTS
}

\author{
M. Grant Norton, David F. Bahr \\ School of Mechanical and Materials Engineering \\ Washington State University Pullman WA 99164-2920
}

\section{Introduction}

To increase the awareness of materials among the general student population at Washington State University (WSU) we developed a new course, MSE 440 Materials: The Foundations of Society and Technology. This course is taught as a Tier III course in the General Education Program and was offered for the first time in Fall 2000, and has now been offered three times. The General Education Program at WSU is an integrated program where students complete a broad program of study in the Arts and Humanities, Social Science, and Sciences. The Tier III courses are only open to students who have completed at least 60 credit hours of course work and their Tier I and Tier II course requirements. The role of Tier III courses is that they provide a high level of discussion and research in a general education area, but do not require prerequisites in the course area.

In this paper we will describe

- The rationale for the development of this course,

- The topics that are covered,

- The way the course is taught,

- Student feedback, and

- Plans for the future.

The importance of increasing the knowledge and awareness of all students, as citizens in a society increasingly dependent upon science and technology, to areas of science and engineering is of paramount importance. For more than two decades materials science has been highlighted by federal agencies such as the National Science Foundation (NSF) as one of the key areas for support in both research and education. The National Research Council has stated that: "Materials have been central to the growth, prosperity, security, and quality of life of humans since the beginning of history"1. Yet the field, and its importance, remains little known, understood, and recognized outside of those in the Science, Mathematics, Engineering, and Technology (SMET) areas. As Martin Green, the 2001 President of the Materials Research 
Society (MRS) stated: "We have not tried very hard to educate the public in the past. It is very important that we not continue to make that mistake" 2 .

Educating future engineers about materials is an important issue and one that is being addressed at many universities, community colleges, and high schools throughout the country. However, educating all students about this important technological field is also an area that must be addressed. The reasons why graduates not in SMET fields should understand the importance of various fields of engineering and science are clear if one looks at the composition of the Washington State legislature. The majority of the legislature has degrees in business, economics, and the liberal arts. In the Technology, Telecommunications, and Energy committee, for example, none of the principal legislators has a technical background. Yet these people are making important, in some cases crucial, decisions that affect the entire State.

Our goals for the course are to

- Provide non-engineering students with the background needed to understand the role of materials in the development of technology and society across the globe.

- Challenge students to examine how materials affect their lives.

- Demonstrate how materials are crucial to the US economy.

Our goals are clearly in line with the challenges for engineering education in the $21^{\text {st }}$ century elucidated by Rita Colwell, the Director of NSF who said "Engineering education must focus on .... technological education of the general public"3.

\section{The Course}

MSE 440 Materials: The Foundations of Society and Technology highlights the historical role that materials have played in human development and their impact on society and technology in the past, present, and future. The course fulfills a student's general education Tier III requirement for a course grounded in scientific methodologies.

Materials have played such a key role in human history that eras have been named after themthe Stone Age, the Bronze Age, and the Iron Age. Today, materials continue to play a pivotal role in society and technology, from determining the mechanisms by which we communicate to how far we can drive a golf ball. Materials have made possible many of the great advances in the $20^{\text {th }}$ century such as the integrated circuit and optical fibers. However, the challenges for the $21^{\text {st }}$ century are even greater. With valuable sources of raw materials becoming depleted and our reliance on fossil fuels becoming untenable, new materials solutions are needed. These solutions have come in the form of recycling, new materials for more efficient use of energy, using materials to harness alternative energy sources, and more environmentally conscious mate rials selection. This course explores the role that materials have played in human development. It also examines advances that have been made in various areas of society and technology and link these advances to the use of new materials. The economic impact of materials in the US and globally in terms of mining practices, manufacturing, recycling, and energy usage, are discussed. 
WSU has a semester-based course system and MSE 440 Materials: The Foundations of Society and Technology is taught in a single fifteen-week semester. The topics covered are summarized below and each is designed to be covered in three 50-minute class periods.

\section{Week 1: History of Materials I}

- Defining periods of human development by specific materials.

- Stone Age-use of naturally occurring materials; shaping; applications.

- Early ceramics; abundance of clay minerals, composition of earth's crust, ancient ceramic masterpieces.

- Bronze Age. Start of metals being more than currency/adornments. First human-made alloys. Materials design -- the early stages.

Week 2: History of Materials II

- The Iron Age: processing of iron.

- Properties of iron -- why was it so important.

- Ancient ironmasters. Steel; attempts at controlling carbon content.

- The Industrial Revolution.

\section{Week 3: History of Materials III}

- The "Plastics Age". The 1960s development of many different plastics. The background to these developments.

- Growth of chemical giants.

- The "Semiconductor Age"; the new technology. What led to the discovery of semiconductors? Why were they needed? How did the technology begin to develop?

\section{Week 4: Where Do Materials Come From?}

- Distribution of raw materials, mining and extraction.

- Location of industries near sources of raw materials.

- Economic and sociological impact of mining practices.

- Case studies: diamond mining in southern Africa, the history of DeBeers. Synthetic diamonds.

- Extraction of aluminum from bauxite in the northwestern US.

- Raw materials locations worldwide, and the impact on various cultures.

Week 5: Shaping and Forming

- Processes used to shape and form materials.

- Relationship between processing and general availability of materials. Examples include the float glass process, one of the major innovations of the $20^{\text {th }}$ century, as well as processes used for metal fabrication.

\section{Week 6: Materials in Medicine}

- Materials that have impacted a variety of medical procedures.

- Hip implants, heart valves, eyeglasses, and current research in bio-mimetic bone growth are discussed.

Week 7: Materials in Sports

- Development of materials in sport and recreation.

- Ethical issues associated with the use of new materials.

- Case studies: tennis racquets, skis, golf clubs. 
Week 8: Materials in Buildings and Construction

- Structural materials used in architecture as well as civil engineering. Steel for skyscrapers. Concrete and pre-stressed concrete. Architectural and energy efficient glasses.

- Microstructure of wood. Manufactured wood products such as engineered lumber.

Week 9: Materials in Communications and Computing

- Paper: the medieval equivalent of the silicon chip.

- History of the transistor. Development of the integrated circuit. Impact of semiconductor technology (largest manufacturing industry in US).

- Copper wires and optical fibers.

- Information storage using CDs, magnetic discs.

\section{Week 10: Materials in Transportation}

- Nickel base superalloys.

- Lightweight composites for aircraft such as Voyager (lightweight aircraft went around the world without refueling).

- HSLA steels vs. aluminum in automobiles.

- Materials in advanced transportation such as the space shuttle.

- Magnetic levitation.

Week 11: The Materials of War

- Importance of materials superiority in war. Revisit, Bronze Age and Iron Age.

- Armor.

- Materials used during the first and second world wars.

- Infrared (night) vision systems.

Week 12: Development of New Energy Sources

- Solar cells and fuel cells.

- Role that materials play in harnessing alternative sources of energy.

- Development of electric automobiles.

- Impact on developing economies and remote locations.

\section{Week 13: The Impact of Materials Failure}

- Fatigue, corrosion, stress-corrosion cracking.

- Economic aspects, effect on GDP.

- Social impact.

- Case studies: RMS Titanic, Sioux City United Airlines crash, Challenger disaster.

Week 14: The Practice and Economics of Recycling

- How are materials recycled?

- Economics of recycling.

- Aluminum, steel, glass, polymers.

The expected student outcomes of the course are:

(a) An appreciation of the historical development of one type or class of material or the historical development of one specific application that coincided with changes in materials.

(b) An awareness of the specific impact that materials have had in the student's major field of study.

(c) A knowledge of the impact of materials in a current area. 
We assess the outcomes by requiring each student to write a paper under the general topics:

(a) An historical perspective.

(b) The impact of materials on the student's major.

(c) Current topics.

Students are also given a weekly quiz to assess their understanding of a particular topic. The quiz grade together with the grades on the papers determines the overall course grade.

As mentioned earlier, our course is targeted towards students with non-SMET backgrounds. Table I shows the majors that have participated in the course over each of the three semesters it has been offered. (The data for Spring 2002 is based on early registration information at the time of writing.) The number of different majors taking the course each semester has increased from 8 (Fall 2000) to 15 (Spring 2002) indicating that we are being successful in reaching out to students in the broad university community. The other observation that can be made from Table I is that each time the course is offered we are retaining students in a major that have already taken the course. For example, students majoring in architecture have taken the course every semester it was offered. Our first business majors took the course in Fall 2001 and students from that major have registered again for Spring 2002. This observation indicates that students in majors that have taken the course are enjoying it and finding it of interest and recommending it to their colleagues. The course has a cap of 40 students per semester. This number allows us to engage in discussion sections with the entire class. Larger course numbers would be possible but may limit the possibility of faculty-student and student-student interactions.

Table I. Majors enrolled in MSE 440 by semester (total number of students)

\begin{tabular}{|l|l|l|}
\hline Fall 2000 (18) & Fall 2001 (33) & Spring 2002 (29*) \\
\hline Architecture & Architecture & Architecture \\
Construction Management & Construction Management & Construction Management \\
Agriculture & Agriculture & Agriculture \\
Education & Computer Science & Animal Sciences \\
Computer Science & Physics & Communication \\
Physics & Marketing & Management \\
Electrical Engineering & Crop Science & Biology \\
Management and & Business & Materials Science \\
\multicolumn{1}{|l}{ Information Systems } & Business Administration & Management and \\
& Mechanical Engineering & Information Systems \\
& Communication & Education \\
& Genetics and Cell Biology & Physics \\
& & History \\
& & Natural Resources-Wildlife \\
& & Ecology \\
& & Bus. Admin.-Real Estate \\
& & Bus.Admin.- \\
& & Entrepreneurship \\
\hline
\end{tabular}

* Based on early registration data. 


\section{Student Feedback}

The student response to date that we have received for this course has been extremely positive. In addition to receiving very high overall student responses on the standard College of Engineering student evaluation forms we have also received positive feedback from our own questionnaire that we distribute to the students at the end of each semester. The questionnaire that we developed seeks to find out how the students felt about the course, the areas/topics that they liked/found most useful and also recommendations they have for improvements in the course for future semesters.

Some of the data obtained for Fall 2001 is summarized in Table II. In the questionnaire 5 was classified as the strongest positive response, 3 a neutral response, and 1 the strongest negative response.

Table II. Student Responses to Questionnaire Fall 2001 (26 surveys)

\begin{tabular}{|l|l|}
\hline \multicolumn{1}{|c|}{ Question } & Response (out of 5) \\
\hline \multicolumn{1}{|c|}{ Student Satisfaction } & \\
\hline Did you like the course & $4.1 \pm 0.6$ \\
\hline Would you recommend the course & $4.6 \pm 0.5$ \\
\hline Was the course relevant to your major & $3.4 \pm 1.2$ \\
\hline Knowing what you now know would you have taken this course & $4.3 \pm 0.8$ \\
\hline How would you compare this class to other GER courses you have taken & $4.0 \pm 0.7$ \\
\hline \multicolumn{1}{|c|}{ Course } & \\
\hline Was the number of topics covered about right & $4.2 \pm 0.6$ \\
\hline Were there additional topics you'd have liked covered & $2.8 \pm 0.7$ \\
\hline Was the course too heavy on engineering & $2.3 \pm 1$ \\
\hline $\begin{array}{l}\text { Did the assignments give you a greater appreciation for the role of } \\
\text { materials in society }\end{array}$ & $3.4 \pm 0.9$ \\
\hline Did the quizzes help you learn the course material & $3.4 \pm 0.9$ \\
\hline Would this course have benefited being co-taught by liberal arts faculty & $1.7 \pm 0.9$ \\
\hline
\end{tabular}

The survey data indicate a high level of student satisfaction with the course and in particular when compared to other general education courses the students have taken. The survey indicates that students may have difficulty in seeing how materials impact their major. This result is perhaps not surprising considering the broad range of majors in the course. Architecture majors, for example, clearly see how developments in materials have changed how buildings are designed and constructed. But a student in Genetics and Cell Biology may have more difficulty appreciating what impact materials have had in that field based on the topics we cover. The implication for us as the teaching faculty is that we have to help students make these connections, particularly as we seek to increase the number of majors represented. This survey result is consistent with the observation that students tend to find most difficulty in the second paper, which asks them to discuss the impact of materials in their major. One frequent criticism that the students have of the course as it is presently structured is that there is no suitable textbook. We do provide extensive notes for the students on each of the course topics and also 
help students find relevant articles from magazines such as JOM, MRS Bulletin, and Invention \& Technology.

\section{The Future}

Our goal of increasing the awareness of materials and materials science among college graduates from non-science and non-engineering disciplines is being achieved locally by our course MSE 440 Materials: The Foundations of Society and Technology. We will continue to offer this course every year at WSU and plan to increase both the number of students taking the course and the number of majors represented. We are hoping to expand our goal to include students at other institutions by developing and disseminating information to allow similar courses to be established elsewhere.

\section{References}

1. "Materials Science and Engineering for the 1990s: Maintaining Competitiveness in the Age of Materials", National Research Council, National Academy Press, Washington D.C., (1989).

2. "Materials Science: You Mean Like Clothes", Letter From the President, Materials Research Society http://www.mrs.org/publications/bulletin/2001/jan/pres_letr.html.

3. “A New Visionary at NSF”, ASEE Prism, January 1999, pp. 34-26.

\section{Biographical Information}

M. GRANT NORTON is Associate Professor in the School of Mechanical \& Materials Engineering and Chair of the Materials Science Program. He has won several awards for teaching including the ASEE Outstanding Teaching Award for the Pacific Northwest in 1996. Dr. Norton has over 100 publications in the archival literature and is coauthor of X-Ray Diffraction: A Practical Approach published by Plenum (1998).

DAVID F. BAHR is Assistant Professor in the School of Mechanical \& Materials Engineering. He received the Outstanding Teaching Faculty Award in Materials Science and Engineering at Washington State University in 1999 and was a recipient of a PECASE/DOE Presidential Faculty award in 2000. Dr. Bahr has over 20 publications in the archival literature. 